\title{
THE CORE OF WAJO CONFEDERATION: ARCHAEOLOGICAL SURVEY IN TOSORA, CINNOTABI AND LAMASEWANUA
}

\author{
Inti Konfederasi Wajo: \\ Survey Arkeologi di Tosora, Cinnotabi dan Lamasewanua \\ Moh. Ali Fadillah ${ }^{1 a}$, M. Irfan Mahmud ${ }^{2 b}$, Budianto Hakim ${ }^{3 c}$ \\ ${ }^{1}$ Depart. of History Education, Faculty of Education and Teaching, University of Sultan Ageng Tirtayasa \\ Jalan Raya Ciwaru Nomor 25 Serang, Indonesia \\ ${ }^{2}$ Balai Arkeologi Provinsi Sulawesi Selatan \\ Jl. Pajjaiyang No. 13 Sudiang Raya Makassar, Indonesia \\ aali.fadilah@untirta.ac.id; birfanarkeologi@yahoo.co.id; cbudianto.hakim@yahoo.co.id
}

Received: 04/09/2020; revision: 11/10-30/11/2020; accepted: 30/11/2020

Published online: 30/11/2020

\begin{abstract}
Abstrak
Awal berdirinya Wajo dimulai dengan migrasi orang dari berbagai tempat untuk membuka sawah dan membangun pemukiman di sebelah timur Danau Tempe. Pemukiman tersebut kemudian menjadi unit politik yang berbentuk 'negara' di bawah pemerintahan seorang bangsawan yang berbasis di Cinnotabi. Beberapa kesepakatan politik mendasari pembentukan konfederasi tiga domain. Perubahan rezim mengakibatkan pergeseran pusat pemerintahan. Lontara Wajo dan tradisi lisan menyebutkan beberapa toponim tetapi tidak menjelaskan secara detil di mana letak inti dari konfederasi Wajo. Penelitian ini bertujuan untuk menentukan lokasi dan karakter toponim dengan melakukan survei lapangan di tempattempat yang diduga terkait dengan keberadaan ibu kota pra-Islam Wajo. Menggunakan pendekatan arkeologi dan didukung informasi dari sumber tekstual. Survei di Desa Tosora, Cinnongtabi dan Tajo di Kabupaten Majauleng telah mengidentifikasi keberadaan ibu kota lama di sekitar Wajo-wajo, Boli, Leppadeppa, Attunuang, dan situs lain berdasarkan jejak arkeologi seperti menhir, pecahan tulang yang terbakar, pecahan gerabah dan keramik serta artefak lainnya. Identifikasi fragmen keramik impor dari China, Thailand, Vietnam, situs-situs ini mungkin bertanggal antara abad XIV dan XVII. Dengan memperhatikan konsentrasi artefak dan relasi antar situs, maka dapat disimpulkan bahwa Tosora adalah ibu kota dari akhir abad XVI dan hingga datangnya Islam pada awal abad XVII, sedangkan ibu kota periode awal Wajo secara hipotetis berlangsung antara awal abad XV dan akhir abad XVI berada di sekitar pertemuan sungai Wajo-wajoe yang mengalir ke danau Latamperu dan Penrange yang kemudian bermuara di Salo Cellue sebelum berakhir di arus utama Cenrana.
\end{abstract}

Kata Kunci: Sulawesi Selatan, Kerajaan Bugis, Konfederasi Wajo, Tosora, Cinnotabi.

Abstract
The beginning of Wajo's establishment began with the migration of people from various places to open
rice fields and build settlements to the east of Lake Tempe. The settlements were then transformed into
political units which formed a 'state' under the rule of a nobleman based in Cinnotabi. Several political
agreements underlie the formation of a confederation of three domains. Regime change resulted in the
transfer of the center of government. Lontara Wajo and the oral tradition mention some toponyms but
do not explain in detail where the core of the Wajo confederation lies. This research is aimed at
determining the location and character of the toponym by conducting field surveys in places that are
suspected of being associated with the existence of the pre-Islamic capital of Wajo. Using an
archaeological approach and supported by information from textual sources. Surveys in the villages of
Tosora, Cinnongtabi and Tajo in Majauleng District have identified the existence of the old capitals
around Wajo-wajo, Boli, Leppadeppa, Attunuang, and other sites based on archeological traces such as
menhirs, burned bone fragments, pottery and ceramics shards and other artifacts. Identification of

Copyright @Jurnal Walennae - Balai Arkeologi Sulawesi Selatan | 131 
imported ceramic fragments from China, Thailand, Vietnam, these sites might be dated between the $14^{\text {th }}$ and $17^{\text {th }}$ centuries. Taking into account the concentration of artefacts and relations between sites, it can be concluded that Tosora was the capital from the end of the $16^{\text {th }}$ century and until the arrival of Islam at the beginning of the $17^{\text {th }}$ century, while the capital of the early period of Wajo hypothetically was dated between the beginning of the $15^{\text {th }}$ century and the end of the $16^{\text {th }}$ century was around the confluence of Wajo-wajoe river which flows into Latamperu and Penrange lake which then empties into Cellue river before ending at the Cenrana mainstream.

Keywords: Sulawesi Selatan, Kingdom of Bugis, Wajo Confederation, Tosora, Cinnotabi.

\section{INTRODUCTION}

The importance of the emergence of the early kingdoms in South Sulawesi was based on the fact that culturally the concept of the State showed certain distinction from other places in Java and Sumatra which were heavily influenced by Indian cultural influences. The existence of the Bugis and Makassar States is revealed by many manuscripts and has also been confirmed by archaeological traces (Macknight, 1975, pp. 127-128). However, the problem is that people often fall into the trap of extrapolation in combing its early history because most of the kingdom, with the specificity of Wajo of course, started with a character who descended from the sky in the form of To Manurung as the forerunner.

In order to clear up the ambiguity between legendary and factual kingdoms which are largely scientific attempts to identify the events involved, (Abidin, 1983, pp. 483-486) has tried to solve this riddle by proposing some hypothesis to reconcile elements of mythology and history fact by relying on various Bugis and Makassar manuscripts. The evidence for this hypothesis is worthy of starting Wajo's early history.

The important points of the hypothesis include three aspects. First, the origin of the formation of Wajo which does not have the concept of To Manurung, but begins with a spiritual leader who is necessary for community formation. Secondly, related to political contracts as the basis for exercising power where a place and ritual is a testimony in an agreement. The third point, the establishment of Wajo is based on the awareness of le désir d'être ensemble under the spirit of spirituality and morality. And the fourth is related to leadership reform from the title Hindu (Batara) to a local title, Arung Matowa, where the king is elected from one of the nobles by the customary council so that the Wajo system of government is called aristocratic democracy (Pelras, 1996, pp. 178-178).

The brief scheme of Wajo's early history as reviewed from several chronicles presents at least four periods of government, which chronologically began with the Primus Inter-pares regime, Arung Cinnotabi, continued to the Batara Wajo and ended in the Arung Matowa regime (Abidin, 1983, p. 482). The first issue began with the opening of settlements by residents from other places, then gathered under the leadership of the spiritual leader Puangnge ri Lampulungeng, and continued by Puangnge ri Timpengeng, which is thought to have lasted since the end of the $14^{\text {th }}$ century. From written sources and oral traditions, two toponyms are obtained: Penrang and Boli, which need to be traced to determine the origin of the first settlement. The problem is where are Penrang and Boli and when did the pre-Wajo settlement formed?

The second issue starts with the formation of a 'State' in which La Paukke, said to be of Cina and Bone descent, appears as the ruler to whom the chiefs of settlements (wanua) integrate the community. The text of Lontara Sukkuna Wajo (LSW) mentions a toponym: Cinnotabi as the center of government with La Paukke as the first 
Arung Cinnotabi and successively replaced by its descendants until La Tenribali and La Tenritipe, two people in the position of Fifth Arung. In this phase we need to know where the location of Cinnotabi, which is estimated to have lasted since the first half of the $15^{\text {th }}$ century, and how long did it function as the center of government?

The third issue starts with Cinnotabi's chaotic situation which necessitated a regime change. La Tenribali was chosen to be the forerunner of the new regime with the title Batara Wajo. Sources say that Batara Wajo ruled in a place called Boli until the reign of third Batara, La Pattedungi, who dramatically had to be resigned for opposing the adat council. A textual source informed that Boli was the seat of the regime's government, so it is necessary to know whether Boli is in the same place as Cinnotabi, or is it in a new location?

The fourth issue, starting with the formation of a new regime in the Wajo government. This phase likely occurred in the second half of the $15^{\text {th }}$ century. Based on the agreement in Leppadeppa, the new regime used the title Arung Matowa in which La Palewo To Palippu was the first ruler. The LSW text states that the capital remains in Boli, but has since changed to Wajo, as a warning to the agreement under the shade of the Bajo or Wajo tree. Abidin wrote in his article:

"It was agreed to change the name of Boli into Wajo', because the covenant was set up under a tall bajo' tree, symbolizing the function of the kingdom and its patronage. The expression in the contract ma'bajowajo macekke'mi ri Wajo" (we only get shelter under the fresh Wajo' shadow affirms this metaphor) (Abidin, 1983, p. 478).

This information can be interpreted as saying that there is no shift in the center of government but it needs an explanation whether Boli and Wajo constituted two names to mention one place? The answer to this question will lead us to the capital of Wajo from the Arung Matowa regime. The problem is that we are introduced to Tosora which is interpreted as the capital of Wajo as well Akin Duli clarifies in his article (Duli, 2010, p. 157), but when Tosora started to become the capital of Wajo, that's a question that also inspired this research.

\section{METHOD}

This research was inspired by the major themes of the Bugis civilization that grew since the $13^{\text {th }}$ and $14^{\text {th }}$ centuries as evidenced by archaeological research at the Alangkanangnge and Tinco sites where there was an abundance of artifacts and other archaeological features. The character of the site proves that the central plains of South Sulawesi have become a link in the golden period of Southeast Asian commerce which was marked by a 'market boom' in the maritime silk route scope (Reid, 2011, pp. 75-76). In this maritime route, it can be seen from the ship wreck of how ceramic goods from China are very dominant as a luxury commodity for ports in Indonesian waters (Harkantiningsih, 2013, pp. 84-88) and similar ceramic fragments were also found in most archaeological sites in South Sulawesi (Hadimuljono \& Macknight, 1983).

The success of the research at Allangkanangnge cannot be separated from a careful study of Bugis textual sources: the I La Galigo cycle and other Bugis lontara texts, so that this research is able to highlight the importance of the economic foundations of the pre-Islamic Bugis state (Bulbeck and Caldwell, 2000, pp. 104-105). This is what Ian Caldwell once said:

"Historians can provide hypotheses of the spatial organization of the Bugis kingdoms which may be tested by archaeologists through an analysis of ceramic shards and other artefacts 
found at most pre-Islamic occupation sites" (Caldwell, 1995, p. 418).

So, referring to the incomplete historical content in the early phase of Wajo, archaeology can fill it with material culture from places that are suspected of containing traces of old settlements. The research location was focused on three administrative villages: Tosora, Cinnong-tabi and Tajo in the Majauleng District, Wajo Regency.

The first stage is to collect information as accurately as possible, so that with the concentration and distribution of artefacts in spaces that are assumed to have strong relationships, they can determine the location, time, character and inter-location associations as well as functional relationships between artifacts and events described in the text. Therefore, the main objective of the survey was to find where the point indicates the core-Wajo as described in the LSW text, as an evolutionary process from a small settlement of ana'wanua class to wanua, then transforming into the CoreWanua, the center of the Wajo confederation (Fadillah, 2004, pp. 353-354).

Furthermore, the research seeks to find traces of spatial shifting from one place

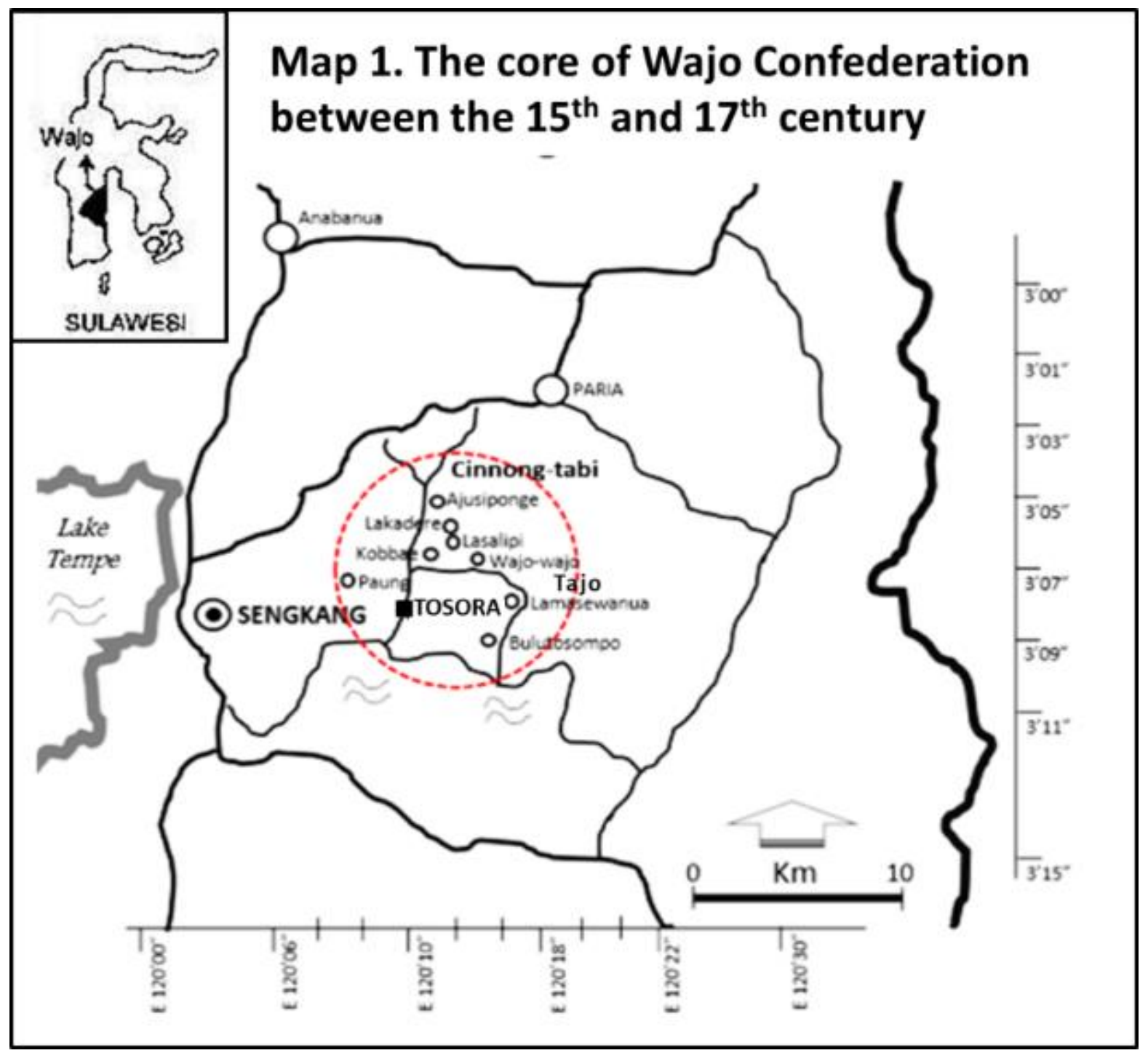

Figure 1. The Core of Wajo Confederation between $15^{\text {th }}$ and $17^{\text {th }}$ Century (Source: Fadillah, 2020) 
to another in a vertical or horizontal relationship. This research is based on a theory about the growth of settlements which gives a dendritic character. The historical geography approach in finding the initial cities and states in South Sulawesi is the key to unlocking the obscurity of Wajo's early history, it must be admitted that it inspired the operationalization of the concept of Bugis civilization in Wajo kingdom. With the formula given by Klukhohn it is necessary to look at the site based on three main variables: writing, population, and religious monuments (Macknight, 1975, p. 127).

Written evidence is readily available in the form of LSW and other manuscripts, so the survey task must rediscover other traces of the past: the concentration of the population and the ritual center. Then the survey will be directed at former settlements as well as places indicating pre-Islamic religious activity which are divided into three zones. Starting with Zone A, which includes a residential area in Tosora village, which is thought to be the last capital of Wajo, Zone B summarizes a number of places in the Cinnong-tabi modern village area on suspicion of being the initial phase of the capital city of Wajo, and Zone C covers the Lamasewana residential area which is now entering in the area of Tajo village which is also considered as the settlement of the early phase of Wajo (see Figure 1).

\section{RESULTS AND DISCUSSION}

\section{Description of sites observed}

a. Zone A: Tosora

The name Tosora refers to a residential unit on a ridge with an altitude between $45-47 \mathrm{~m}$ above sea level. Zone $\mathrm{A}$ is

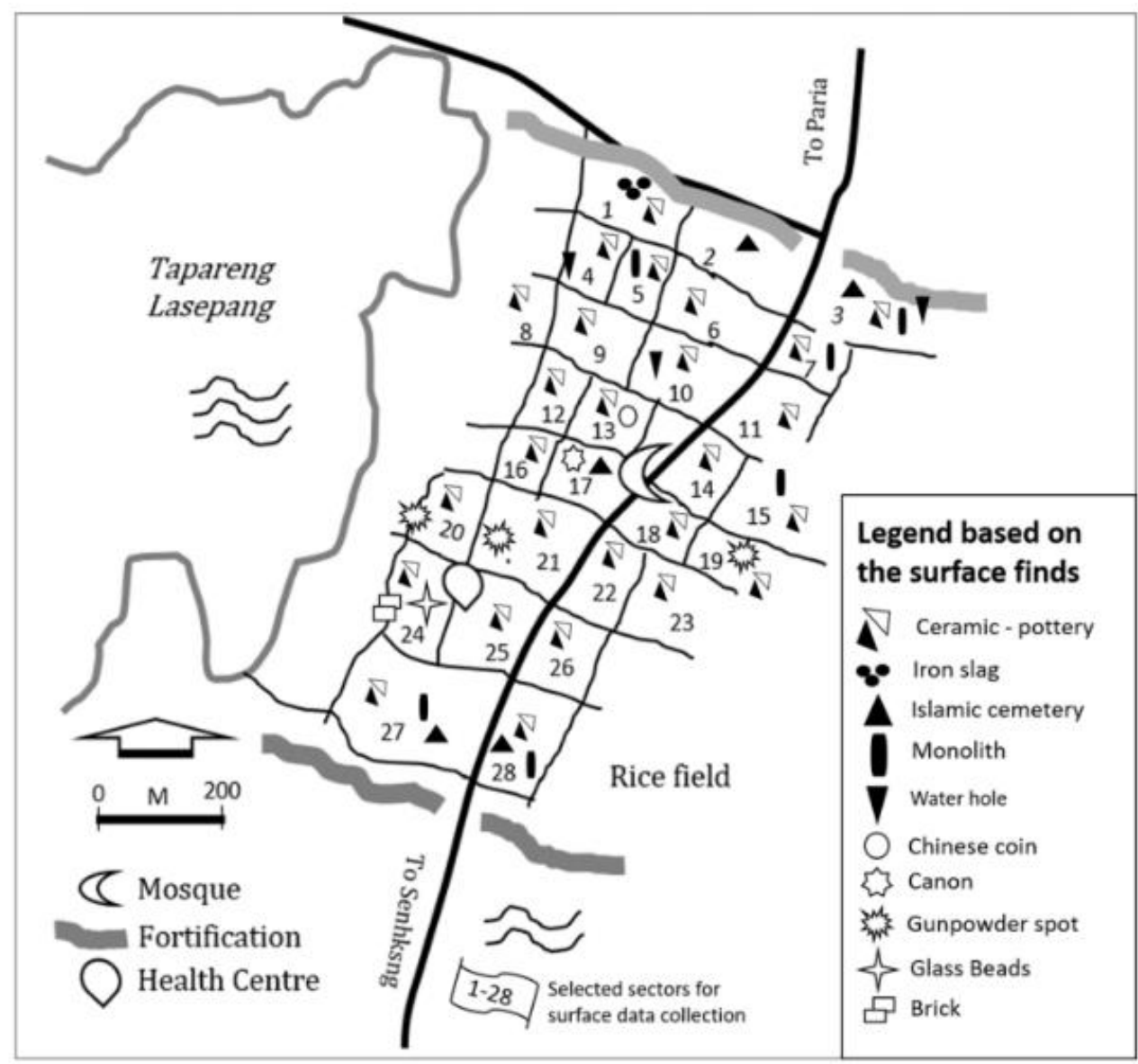

Figure 2. The Site of Tosora (Source: Fadillah. 2020) 
located in Tosora village, Majauleng district, covering residential areas surrounded by forts in the north and south, Laseppang lake in the west and Latamperu lake in the east. The density of houses with various public facilities made it difficult to observe, however archaeological traces were recorded by dividing them into several sectors (see Figure 2).

Traces of Tosora's past are provided by the ruins of an earthen fortress, an ancient mosque and several menhirs and tombs from the pre-Islamic period to the present. There was also activity in the remains of furnaces, iron crust, bullets, a number of cannons, and gunpowder storage (Fadillah, et al., 2002). What is interesting about Tosora, as studied by Kalupa (1987) and Duli (2010), is that there are many shards of pottery and ceramics that are evenly distributed in almost all area. To facilitate the sampling of surface findings, the entire Zone A area is divided into 28 sectors, from north to south of the fort. In fact, not all sectors provide adequate objects, because most of the sites have been closed with new buildings, causing ceramic fragments to only come from 15 sectors while pottery comes from 9 sectors.

\section{b. Zone B: Cinnotabi}

Cinnotabi or pronounced CinnongTabi is now the name of an administrative village in the Majauleng district area. The giving of an old name to an administrative area inspired observations made in that area. For the convenience of data recording, the location which is thought to be the starting point of the Wajo core is marked as Zone B, about $5 \mathrm{~km}$ north of Zone A, precisely in the upstream of the river between Pene-pene in

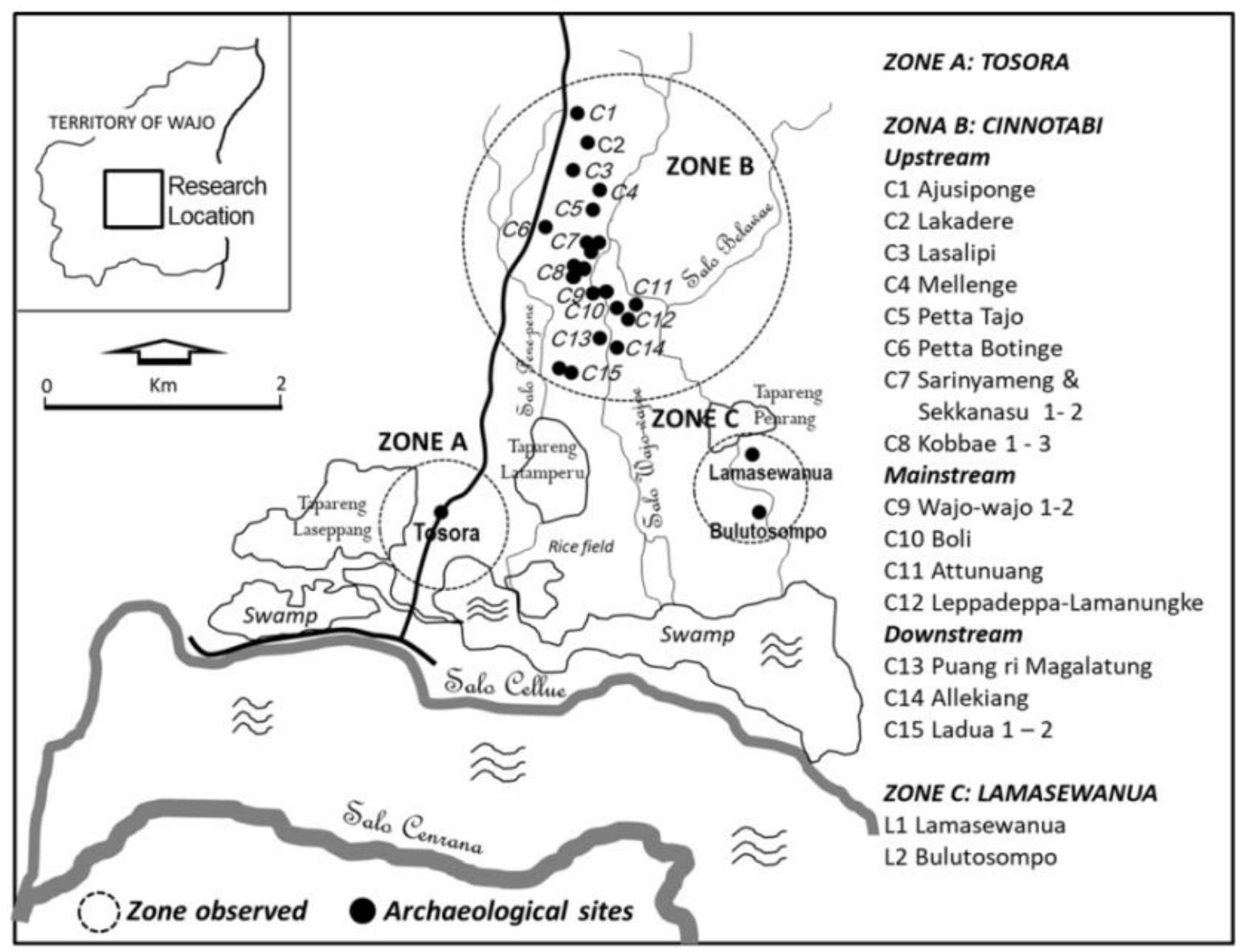

Figure 3. Zone Observed in the Core of Wajo (Source: Fadillah, 2020) 
the west, Wajo-wajoe in the center and Belawae in the east (see Figure 3).

To facilitate observation Zone B is divided into 3 areas. First, the upstream area includes eight sectors $(\mathrm{C} 1-\mathrm{C} 8)$, which are focused on the upstream of the Wajo-wajoe river, namely at the locations of Ajusiponge, Lakadere, Lasalipi, Mellenge, Petta Tajo and Petta Botinge, Sarinyameng and Sekkanasu which are connected by the Wajo-wajoe upstream, linearly showing archaeological symptoms in the environment of sloping hills and rice fields in the valley. An indicator of the usefulness of this area is given by large monoliths (menhirs) to mark the graves of Wajo nobles, clean water sources (wells), pottery shards and imported ceramics especially from the type of stoneware associated with burnt bone remains.

\section{c. Zone C: Lamasewanua}

The designation of Zone $\mathrm{C}$ as one of the observed areas is based on the oral tradition that is considered as the first capital of Wajo under the name Cinnotabi before moving to Tosora. The oral tradition presents ambiguity when referring to the initial assumptions. Administratively Zone $\mathrm{C}$ is included in the area of Tajo Village, Majauleng district. With the topography surrounded by swamps behind the Wajowajoe and Belawae rivers, this zone has direct access to the large river, Salo Cellue, so to ensure the existence of archaeological evidence, it is necessary to observe a location that leaves contemporary traces (see Figure 3).

The survey is directed at the L1, L2 and L3 sectors. Observations started from the upstream direction, namely a village called Lamasewanua downstream to Bulutosompo. This zone is the eastern boundary of the capital Tosora, which is directly adjacent to Wanua Penrang, a member of the Wajo confederation in the Tuwa domain (Pelras, 1971, I, p. 17). Two sectors (L1 and L2) provide quite significant information, namely in the form of menhirs that mark the origin of settlements, and the concentration of ceramic and pottery fragments. Surface artefact sampling is required for the relative dating of this sector. Likewise, in the downstream area called Bulutosompo (L2) it is still feasible to donate ceramic and pottery shards, even though there have been many physical disturbances from residents' activities.

\section{Contextual Analysis}

The analysis phase is directed at two types of artifacts resulting from the survey, namely fragments of pottery and imported ceramics, while monuments in situ serve as supporting data. Zone A (Tosora) provides almost all elements of modernity: recent objects: buildings and infrastructure, so arguably Tosora represents a modern village in South Sulawesi. However, in terms of topography, Zone A has not undergone a total transformation. This zone still gives traces of occupancy from several centuries ago. Evidence of Tosora's past activities are still visible, some in situ are partly redepositioned, and of course, no longer in an archaeological context.

The first phenomena of the past are the earthen fortress on the north and south sides, indicating Tosora as an intra-murros settlement unit; the same symptoms were found in the political centers in other Bugis lands and also in the areas where the kings of Makassar were always surrounded by fortresses (Bulbeck, 1992). Secondly, there are still many monoliths or in a special sense menhirs, pre-Islamic traditions that are still preserved, on the north and south sides and in the middle, such as the same object on the Cilellang site that is attached to religious functions (Hasanuddin, 2017, p. 87), but from another perspective, it could also be related to the spiritual legitimacy of the government regime (Pelras, 1996, pp. 178179). The existence of an Islamic grave in the vicinity shows the public's perception of the sacred character of a stone monument. 


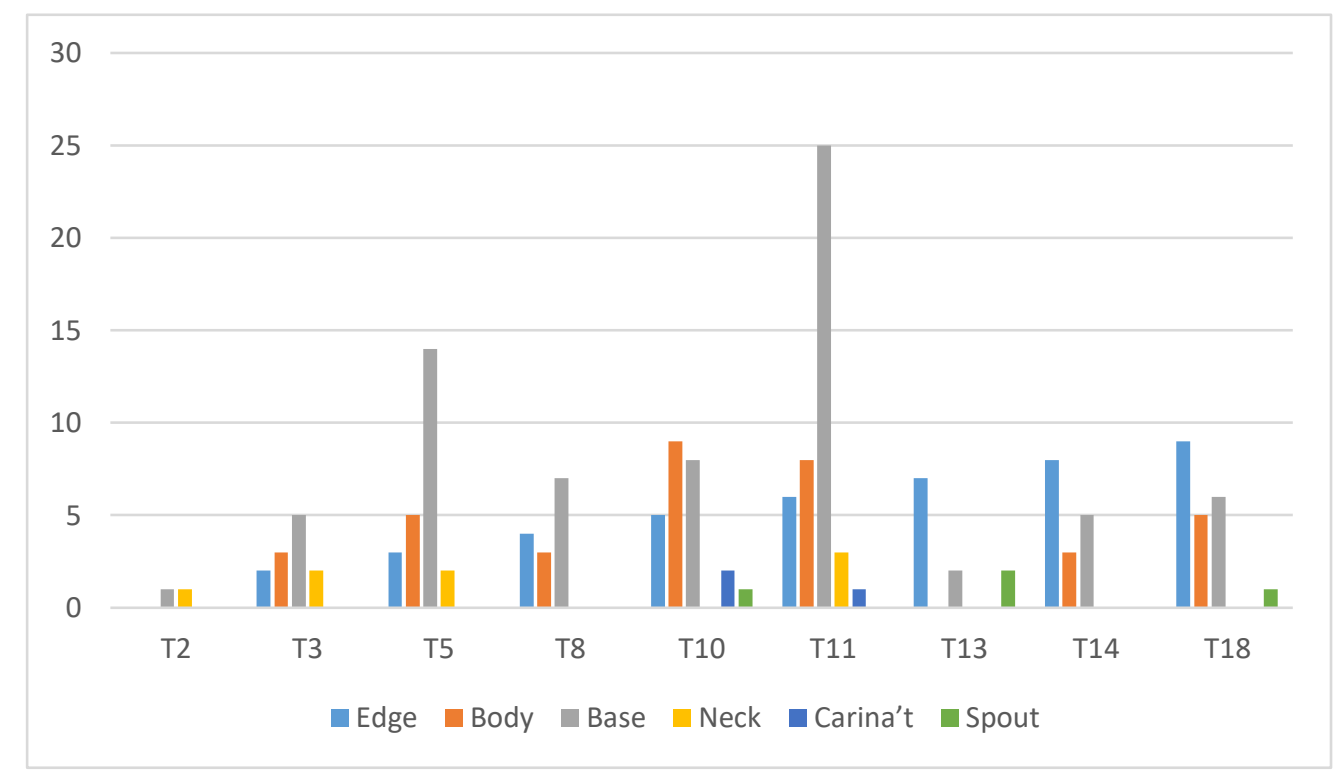

Figure 4. Diagram of Pottery Shards in Zone 1 Tosora

The archaeological context of menhirs must end after the arrival of Islam, with the old mosque testifying strongly to the midpoint of Tosora (Sector T17 and T18); marks a new era of urban settlements in terms of politics, economy and religion.

The third symptom is in the form of slag and iron ore grains, and even more so cannons that have been converted into grave signs, and one more important thing, the arsenal of gunpowder. Like the old mosque, the explosives warehouse is located at the center of Tosora. These hard facts are an indicator that Tosora is a place that is prepared to protect its rulers and their people from outside attacks and that great efforts are needed to conquer it. As a large settlement in its golden era, residents needed other facilities to support their daily lives, so the fourth phenomena was found in the form of old wells, there should be more, but three samples adequately explain efforts to meet clean water needs. It is difficult to prove when the wells were made, but in the context of water as a primary need, it should have been available since settlement existed.

The fifth phenomena is the discovery of a large number of pieces of pottery almost evenly across all sectors. Disturbances undoubtedly degrade the antiquity of the evidence, and require that we look at the distribution and variation in the shape of the sometimes difficult to identify small pieces. Pottery samples in terms of quantity are inadequate compared to site area. Among the 28 sectors surveyed, only nine were obtained fragment samples i.e from the sectors of T2, T3, T5, T8, T10, T11, T13, T14 and T18 (Figure 4). Concentration and quantity are not the main variables determining the intersectoral relations, but to find out the variety of daily activities, pottery can be an early indication of old occupancy. As a result, fragments from 9 sectors show a variety of earthenware associated with food processing. From a total of 121 pieces, assuming that they represent all sectors, at least it will give us a basic notion about daily life of settlement. The largest fraction is the body in almost every sector, while the edge and base are found at the second largest position. A special pottery is indicated by a limited number of spouts and necks. Elements of quality and engineering of pottery art are found in several sectors in the form of polished bodies and edges and also decorated with twists and geometric patterns, especially on the neck, carination, 
Table 1. Distribution of Imported ceramic shard in Zone A: Tosora

\begin{tabular}{|c|c|c|c|c|c|c|c|c|c|c|c|c|c|}
\hline \multicolumn{2}{|c|}{ SECTOR } & \multicolumn{3}{|c|}{ CHINESE } & & & \multicolumn{2}{|c|}{ THAILAND } & $\mathbf{A N}$ & JPN & EUR & U.i & TOTAL \\
\hline & \multirow{2}{*}{$\frac{\text { XII-XIII }}{\text { Lq }}$} & \multicolumn{2}{|c|}{ XIV - XVI } & \multicolumn{3}{|c|}{ XVII-XVIII } & \multirow{3}{*}{$\begin{array}{l}\text { Sw } \\
0\end{array}$} & \multirow{3}{*}{$\begin{array}{c}\text { Suk } \\
\text { o }\end{array}$} & \multirow{3}{*}{\multicolumn{2}{|c|}{$\begin{array}{c}\text { Hizen } \\
0\end{array}$}} & \multirow{3}{*}{$\begin{array}{c}\text { Holland } \\
\text { o }\end{array}$} & \multirow[b]{3}{*}{0} & \multirow[b]{3}{*}{297} \\
\hline & & \multirow{2}{*}{$\begin{array}{c}\text { Cel } \\
2\end{array}$} & \multirow{2}{*}{$\begin{array}{l}\text { Zh } \\
237\end{array}$} & \multirow{2}{*}{$\begin{array}{c}\text { Jng } \\
0\end{array}$} & \multirow{2}{*}{$\begin{array}{l}\text { BW } \\
45\end{array}$} & \multirow{2}{*}{$\begin{array}{c}\text { Cra } \\
1\end{array}$} & & & & & & & \\
\hline $\mathrm{T} 1$ & 5 & & & & & & & & & & & & \\
\hline T3 & 0 & 2 & 10 & 0 & 1 & 0 & 3 & 0 & 0 & 0 & 0 & 0 & 16 \\
\hline $\mathrm{T} 4$ & 3 & 0 & 78 & 0 & 4 & 0 & 5 & 3 & 10 & 0 & 1 & 0 & 104 \\
\hline T6 & 0 & 0 & 0 & 0 & 2 & 0 & 0 & 2 & 2 & 0 & 0 & 0 & 6 \\
\hline T7 & 1 & 0 & 35 & 0 & 18 & 0 & 0 & 0 & 0 & 0 & 0 & 0 & 54 \\
\hline $\mathrm{T} 13$ & 0 & 0 & 0 & 0 & 25 & 0 & 1 & 2 & 0 & 0 & 0 & 0 & 28 \\
\hline T14 & 1 & 5 & 52 & 1 & 19 & 0 & 46 & 0 & 2 & 0 & 0 & 0 & 126 \\
\hline T17 & 0 & 0 & 10 & 0 & 6 & 0 & 0 & 0 & 0 & 1 & 0 & 0 & 17 \\
\hline T18 & 3 & 1 & 99 & 1 & 21 & 0 & 7 & 5 & 0 & 1 & 0 & 0 & 138 \\
\hline T19 & 0 & 0 & 79 & 0 & 7 & 0 & 3 & 7 & 15 & 0 & 0 & 0 & 111 \\
\hline $\mathrm{T} 21$ & 1 & 0 & 126 & 0 & 19 & 0 & 4 & 4 & 7 & 0 & 1 & 0 & 162 \\
\hline $\mathrm{T} 23$ & 1 & 8 & 45 & 0 & 0 & 0 & 7 & 15 & 18 & 0 & 0 & 0 & 94 \\
\hline $\mathrm{T} 24$ & 0 & 6 & 30 & 0 & 0 & 0 & 4 & 22 & 10 & 0 & 2 & 0 & 74 \\
\hline T25 & 1 & 0 & 0 & 0 & 23 & 0 & 14 & 0 & 36 & -0 & 0 & 0 & 74 \\
\hline T27 & 2 & 5 & 0 & 0 & 12 & 0 & 13 & 18 & 25 & 0 & 0 & 0 & 75 \\
\hline TTL & 18 & 29 & 801 & 2 & 202 & 1 & 107 & 78 & 132 & 2 & 4 & 0 & 1,376 \\
\hline & & $\begin{array}{l}\mathrm{L} q=L^{\circ} \\
\mathrm{Cel}= \\
\mathrm{Zh}=\mathrm{Z}\end{array}$ & $\begin{array}{l}\text { uan } \\
\text { adon } \\
\text { gazhou }\end{array}$ & $\begin{array}{l}\text { Jng } \\
\text { BW } \\
\text { Cra }\end{array}$ & $\begin{array}{l}\text { rigdez } \\
\text { ue-W } \\
\text { ackec }\end{array}$ & & $\begin{array}{l}=\text { Saw } \\
=\text { Sukt } \\
=\text { Anam }\end{array}$ & $\begin{array}{l}\text { halok } \\
\text { ai }\end{array}$ & $\begin{array}{l}\text { JPN = Ja } \\
\text { EUR = E } \\
\text { U.i. = Un }\end{array}$ & $\begin{array}{l}\text { san } \\
\text { Irope } \\
\text { dentified }\end{array}$ & & & \\
\hline
\end{tabular}

and edges The presence of local earthenware always coincided with fragment of imported ceramics, providing indicator for the use of local home appliances for everyday use.

The sixth phenomena is shown by ceramic shards in almost every sector. From a total of 1,376 samples taken from 15 sectors (Table 1), various forms of variation can be seen. The results of the analysis resulted in different origins, namely Chinese fractions ranked first, Thailand and Vietnam second. In terms of time, the fraction represents the period between the $15^{\text {th }}$ and $17^{\text {th }}$ centuries. Although the sample found Lonquan shards believed to be products of the Song period (the $12^{\text {th }}-13^{\text {th }}$ centuries), the samples were dominated by Zhangzhou and Blue-White porcelain, as well as Sawankhalok and Anam shards from the $16^{\text {th }}$ to $17^{\text {th }}$ centuries.

Referring to the relative chronology of the fragments leads us to the hypothesis that the occupation of Zone $\mathrm{A}$ is not older than the 16th century and reached its peak of activity at the beginning of the $17^{\text {th }}$ century. This period is a transitional phase before and after the arrival of Islam to Wajo. The variation in shape shows the specific body parts of the stoneware which lead us to the initial speculation; how important stoneware was before the large importation of blueand-white bowls and plates from the Ming period.

The results of random sampling from all sectors have shard concentrations only in the sectors: T13, T14, T18, T19, T21, T23, T24. The seven sectors are around the midpoint, therefore of course, it is not the time yet to interpret this phenomena, but whatever the facts require us to make a note of a palace center in the capital of Wajo. The concentration of fragments is associated with the existence of the old mosque, gunpowder warehouse, canons and also a 


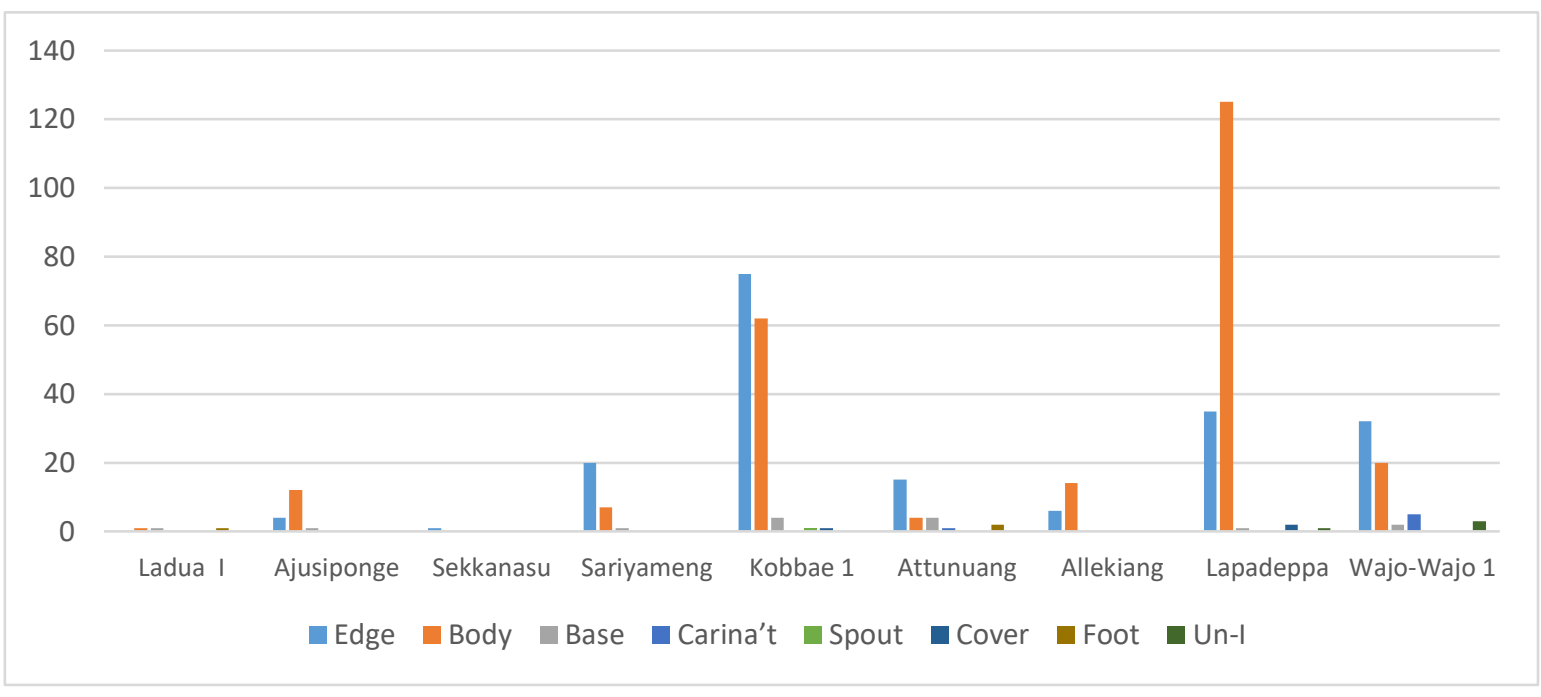

Figure 5. Pottery Shards in Zone 2 Cinnotabi

water source to the north (sector T10). From the context of the findings, it seems that these sectors are the Axis of Zone A, at least the 'hub of all settlement' in Tosora.

The next analysis was directed at Cinnotabi . With regard to this Zone B locus, the farthest point is in Sector C1 (Ajusiponge), about $10 \mathrm{~km}$ from Zone A. The application of the concept of dendritic settlements led to surveys following the river flow to the upper reaches of Wajo-wajoe. Of the eight sectors $(\mathrm{C} 1-\mathrm{C} 8)$ upstream are marked by monoliths on gently sloping hills and fertile valleys along the river flow. To obtain early clues to the existence of past activity, it is necessary to extract archaeological evidence. In fact, local earthenware and imported ceramics in surface are still found today (Figure 5).

With regard to pottery in the upstream part, samples of fragment were only obtained from the Ajusiponge, Sarinyameng, Sekkanasu, Kobbae sectors. With a total of 189 pieces, $75 \%$ was obtained from sector $\mathrm{C} 8$ (Kobbae 1), the rest come from sector $\mathrm{C} 1$ (Ajusiponge), sector $\mathrm{C} 7$ (Sarinyameng and Sekkanasu). Most of it is in the form of body and edges.

Upstream from Zone B, a significant amount of imported ceramic shards was found. Of the total 909 shards originating from Sector C1, C7, and C8 (Ajusiponge, Sarinyameng-Sekkanasu and Kobbae), 729 pieces were identified as belonging to the $15^{\text {th }}$ and $16^{\text {th }}$ centuries, meaning that more than $80 \%$ were greenware, Zhangzhou, Sawankhalok, Sukhotai and Anam ware. The rest is presented by the Jingdezhen and BW type from the $16^{\text {th }}$ to $17^{\text {th }}$ centuries (See Table 2). The shards from the earlier period given by Yue-ware was only one piece, several keeping types of Qingbai and Lonquan. Of all sectors more than half were found in sector C7 (SarinyamengSekkanasu).

In general, the surface find samples indicate that there are traces of occupation in the upstream sector, but it is not yet known whether they are traces of settlements or remains from burials. In addition, it is necessary to consider the importance of the existence of several menhirs and in the later times of the Wajo aristocratic burial complex from the pre-Islamic period in sectors C5 and C6 (Petta Tajo and Petta Botinge).

There is a slight difference when entering the middle part of Zone B which includes the confluence of the river which is centered on Kampung Wajo-wajo. The archaeological phenomenon in the middle of this zone is quite diverse, especially shown 
Table 2. Distribution of Imported ceramic shard in Zone B: Cinnotabi

\begin{tabular}{|c|c|c|c|c|c|c|c|c|c|c|c|c|c|c|c|c|c|c|}
\hline \multirow{2}{*}{$\begin{array}{l}\text { SEC- } \\
\text { TOR }\end{array}$} & \multirow{2}{*}{$\begin{array}{l}\text { TANG } \\
\text { Yue }\end{array}$} & \multicolumn{2}{|c|}{ SONG } & \multicolumn{2}{|c|}{ YUAN } & \multicolumn{3}{|c|}{ MING } & \multicolumn{3}{|c|}{ QING } & \multicolumn{2}{|c|}{ THAILAND } & \multirow[t]{2}{*}{ AN } & \multirow[t]{2}{*}{ HZN } & \multirow[t]{2}{*}{ EU } & \multirow[b]{2}{*}{ U.i } & \multirow[b]{2}{*}{ TOTAL } \\
\hline & & $Q b$ & $\mathrm{Lq}$ & $\mathrm{Dh}$ & Cel & $\mathrm{Gu}$ & Cel & $\mathrm{Zh}$ & Jng & BW & Cra & Swa & Suk & & & & & \\
\hline $\mathrm{C} 1$ & 0 & 0 & 1 & 3 & 0 & 0 & 0 & 52 & 2 & 5 & 0 & 47 & 59 & 81 & 0 & 0 & 1 & 251 \\
\hline C7.1 & 0 & 0 & 5 & 0 & 0 & 0 & 3 & 39 & 0 & 13 & 0 & 21 & 10 & 14 & 0 & 0 & 0 & 105 \\
\hline $\mathrm{C} 7.2$ & 1 & 0 & 5 & 0 & 0 & 0 & 13 & 45 & 0 & 24 & 0 & 81 & 95 & 83 & 0 & 0 & 2 & 349 \\
\hline C7.3 & 0 & 0 & 3 & 0 & 1 & 0 & 0 & 14 & 2 & 2 & 0 & 11 & 9 & 41 & 0 & 0 & 6 & 89 \\
\hline C8.1 & 0 & 3 & 1 & 0 & 0 & 0 & 2 & 2 & 0 & 0 & 0 & 2 & 20 & 5 & 0 & 0 & 0 & 35 \\
\hline C8.2 & 0 & 2 & 3 & 0 & 0 & 0 & 4 & 7 & 0 & 0 & 2 & 4 & 23 & 21 & 0 & 0 & 0 & 66 \\
\hline C8.3 & 0 & 0 & 0 & 0 & 0 & 0 & 2 & 0 & 0 & 0 & 0 & 0 & 12 & 0 & 0 & 0 & 0 & 14 \\
\hline C9.1 & 0 & 0 & 2 & 0 & 3 & 0 & 0 & 3 & 0 & 0 & 0 & 3 & 3 & 0 & 0 & 0 & 0 & 14 \\
\hline C9.2 & 0 & 4 & 7 & 1 & 0 & 0 & 0 & 33 & 1 & 11 & 0 & 24 & 5 & 40 & 0 & 0 & 5 & 131 \\
\hline C11 & 0 & 0 & 0 & 0 & 0 & 0 & 4 & 20 & 2 & 6 & 0 & 14 & 96 & 94 & 0 & 0 & 0 & 236 \\
\hline $\mathrm{C} 12.1$ & 0 & 0 & 4 & 1 & 0 & 0 & 37 & 35 & 15 & 0 & 0 & 8 & 50 & 0 & 0 & 1 & 0 & 151 \\
\hline $\mathrm{C} 12.2$ & 0 & 0 & 4 & 0 & 0 & 0 & 0 & 18 & 1 & 3 & 5 & 2 & 0 & 4 & 0 & 0 & 0 & 37 \\
\hline C15.1 & 16 & 0 & 3 & 17 & 0 & 39 & 12 & 96 & 31 & 13 & 0 & 0 & 18 & 61 & 3 & 1 & 11 & 321 \\
\hline $\mathrm{C} 15.2$ & 0 & 0 & 2 & 0 & 0 & 0 & 0 & 16 & 0 & 10 & 0 & 48 & 54 & 73 & 0 & 0 & 0 & 203 \\
\hline TOTAL & 17 & 9 & 40 & 22 & 4 & 39 & 77 & 380 & 54 & 87 & 7 & 265 & 454 & 517 & 3 & 2 & 25 & 2002 \\
\hline \multirow{2}{*}{\multicolumn{2}{|c|}{ NOTE }} & \multicolumn{17}{|c|}{$\begin{array}{l}\text { C1 = Ajusiponge, } C 7.1=\text { Sarinyameng, } C 7.2=\text { Sekkanasu 1, C7.3 = Sekkanasu 2, C8.1 = Kobbae 1, C8.2 = Kobbae 2, C8.3 = Kobbae 3, } \\
C 9.1=\text { Wajo-wajo 1, C9.2 = Wajo-wajo 2, C11 = Attunuang, C12.1 = Leppadeppa, } C 12.2=\text { Lamanungke, C15.1 = Ladua 1, C15.2 = Ladua } 2\end{array}$} \\
\hline & & & & & & & & & & & & & & & & & & \\
\hline
\end{tabular}

by the large number of pottery fragments and imported ceramic, and also bone fragments, and beads especially in sector C12, namely at a location called Attunuang.

The samples of pottery shards were obtained from 3 locations: Wajo-wajo, Leppadepa, and Attunuang slightly higher than the upstream sector, which was 248 pieces, the largest proportion came from the Leppadepa Sector i.e $64.52 \%$, and then Wajo-wajo $25 \%$, the rest from Attunuang just $10.48 \%$. The pottery fragments need to be viewed from the overall context. Of all the sherd obtained from the ground surface, which is dominated by the body and edges, and in a small proportion in the form of necks, carinations and bases. The body and edges always rank the most, this could be interpreted as being mostly an open container. In terms of quality, it shows its class as shown by several fractions whose outer planes are polished and decorated with geometric patterns.

With regard to ceramic shards, the surface findings in the center part of Zone B are quite diverse. Of the total 492 fragments found in sectors C9 (Wajo-wajo), C11 (Attunuang), $\mathrm{C} 12 \quad$ (LeppadeppaLamanungke) more than $80 \%$ was contributed by fragments from the $15^{\text {th }}-16^{\text {th }}$ centuries in the form of Ming Celadon, from Zhangzhou, Thailand and Anam, then from the $16^{\text {th }}-17^{\text {th }}$ centuries only $16 \%$ marked by Jingdezhen and Blue-White porcelain, the rest from the $13^{\text {th }}-14^{\text {th }}$ centuries provided by Qingbai and Lonquan. If Attunuang is synonymous with the ritual center and Leppadeppa as the place for the political agreement of Cinnotabi reformation, the capital of Wajo can be found in Wajo-wajo, which has been initiated since the Batara Wajo regime, then continued by the Arung Matowa regime by changing its name from 
Boli to Wajo, apparently imported ceramic fragments in Wajo-wajo (Sector C9.1 and C9.2) confirm the location of the LSW toponym.

Now let's examine the downstream part of Zone B which only covers 3 sectors, namely C13 (Puang ri Magalatung), C14 (Allekiang) and C15 (Ladua 1 and Ladua 2). The three locations are located between the Wajo-wajoe and Pene-pene rivers where menhirs are still found but are not directly associated with the function of the tomb. Pottery samples from these locations were only obtained from the Allekiang and Leppadeppa sectors, only 23 pieces, mean of the total $86 \%$ were provided by sector $\mathrm{C} 14$ and only 3 pieces from Sector C15. From that number, it is dominated by edges and bodies, meaning that the shards is relatively the same as other sectors in terms of shape. The discovery of pottery shards here also shows the site occupation, especially for settlements, which is also marked by the presence of menhirs and tombs of nobles from Makassar, Karaeng Ladua.

Meanwhile, the ceramic shards whose samples were quite significant confirmed the existence of residential activities using imported ceramic containers with a total of 524 shards obtained from subsector C15.1 and C15.2. The identification results show that the dominant imported objects are given by ceramic shards from the $15^{\text {th }}-16^{\text {th }}$ centuries, almost $80 \%$ of which come from Guangdong, Zhangzhou, Thailand. In small proportions it is given by the $17^{\text {th }}$ century fragmens of Jingdezhen and Blue-White, and those of Hizen. It should be noted, however, that this sector also provide 16 Yue-type shards. If the identification results are convincing, it will certainly show that the sector has a long duration. In the oral tradition it is stated that Ladua is also referred to as sorengeng kappala, the Bugis word for port.

This surface fact leads us to the suspicion that Ladua is a port to serve trading activities for Zone B. It seems, it is necessary to speculate that the port is still functioning even though the capital according to LSW has experienced several movements, namely from Cinnotabi to Boli or Wajo before moving to Zone A (Tosora). However, ceramics are evidence of trade transactions, while pottery rarity in this place shows the secondary function as a settlement for traders. If this hypothesis can be proven by excavation to determine the initial period and downstream character, it may be noted in particular that the sectors of $\mathrm{C} 14$ and $\mathrm{C} 15$ between the Wajo-wajoe and Pene-pene rivers are more ideal as an entrepot for imported and exported goods through the Salo Cellue. correspond with the Salo Cenrana network to reach the estuary in Bone gulf.

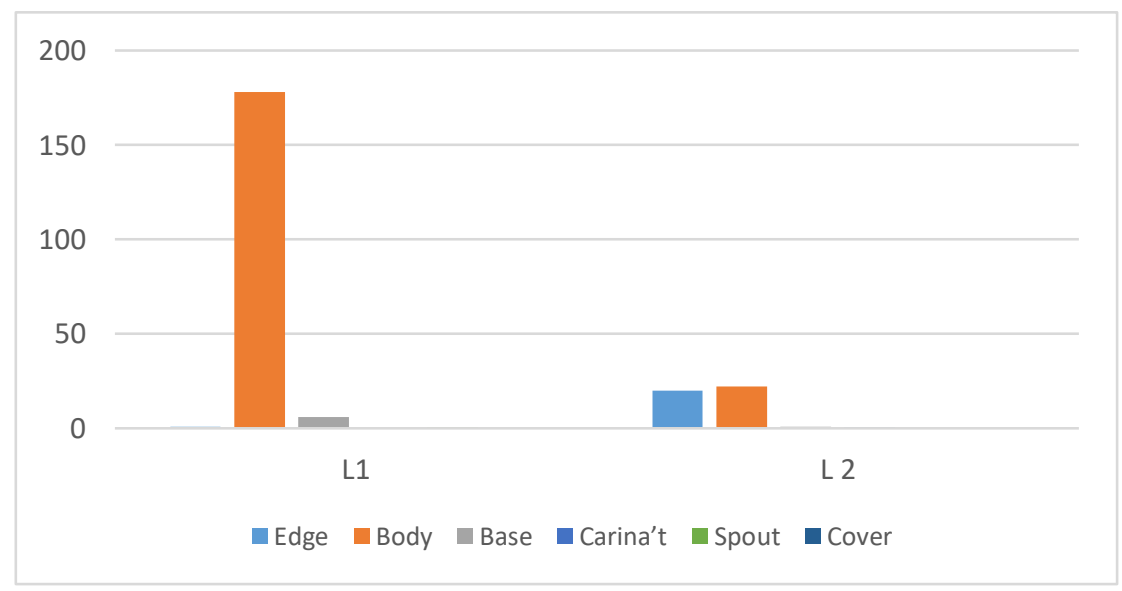

Figure 6. Diagram of Pottery Shards in Zone 3 Lamasewanua 
Finally, it focuses on Lamasewanua which is marked as Zone C. Lamasewanua area is formed by alluvial deposits of the Wajo-wajoe and Belawae rivers. Representing Zone $\mathrm{C}$, taking imported ware samples from Lamasewanua village (Sector L1 and L2), and sector L3, Bulutosompo habitation. Pottery shards from Zone C totaled 256 pieces, but the samples were only collected from the L1-Village and L2-
Cemetery sectors, while those from L3 did not show any shards, even though they were there, most of them were weathered, very probably because this sector was in wetlands, bordering directly to the Latamperu swamp and the back swamp of Salo Cellue.

From the L1 sector, there were 186 pieces of pottery shards with the largest proportion in the form of the body, the rest
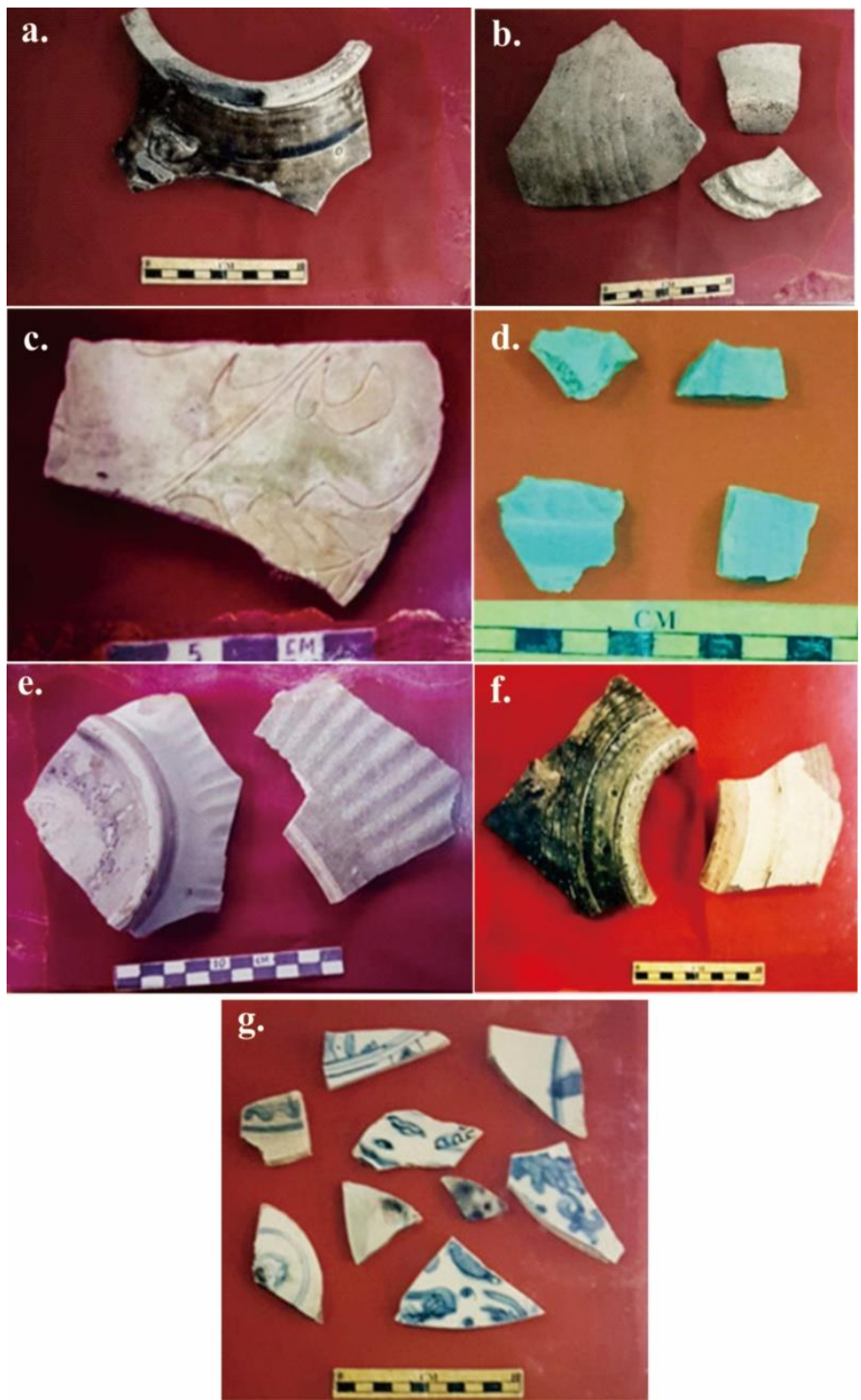

Figure 7. a Vietnamese Ceramic from $15^{\text {th }}$ Century, b. Ceramic Yue-ware (Tang Periode in $9-11^{\text {th }}$ Century), c. Annam Tricolor about 15-16 ${ }^{\text {th }}$ from Wajo-Wajo 2 Site Wajo, d. Lonquan Fragments 13-14 Century Period from Lamasewanuae-1 Site Wajo, e. Celadon Bowl (Chinese Green ware) about $14^{\text {th }}$ century from Sarinyameng Site, f. Sukhotai Jar about $15-16^{\text {th }}$ Century from Attunuang Site Wajo, g. Zhangzhou Fragment 16 to $17^{\text {th }}$ Century from Tosora Site (Source: Fadillah, 2020) 
were only the edges and the base, and 1 piece showed geometric motifs. From the L2 sector, around the old tomb, it was obtained as many as 70 pieces consisting of edges and bodies in relatively equal proportions and 1 piece having geometric motifs. As found in other sectors, body parts are very dominant, especially in the L1 sector. This is in contrast to L2 which has the same proportion between the body and the edges, which is very likely to come from the jars on a site that has not had much interference with current activities. However, in order not to get too far into interpretation, pottery shards are evidence of daily activities and also in the context of burials using local containers in Lamasewanua (Figure 6).

Regarding ceramic shards, the survey in three sectors produced 119 pieces, divided into L1 sector (Lamasewanua Village) with 88 pieces, L2 sector (Lamasewanua Cemetery) with 17 pieces and L3 sector (Bulutosompo) as many as 14 pieces. Of the total shards, there were 64 pieces in the form of Thailand-ware. Meanwhile, 32 Chinese shards were found but they were divided into 13 shards from the Song period (Qingbay and Lonquan), 6 shards from Guangdong and Zhangzhou and 12 shards from Blue-White and Jingdezhen, and one shard could be identified as Yue type. But it is also important to think that the fragments of the Qing period starting from the $17^{\text {th }}$ century have a relatively similar proportion with Vietnam as compared to Thailand. Looking at the composition of the ceramic shards from where they came from, this site also seems to have lived between the 14th and 17th centuries (See Appendix 1 and Figure 7).

Taking into account the topographic position and samples of pottery and ceramic shards, an initial interpretation can be given, that it is likely that Lamasewanua was the main route when the Wajo core was still centered in Cinnotabi and Boli, and the occupation of this place continues into the Tosora period. Its location as a watershed and swamp that was too open, made it impossible to become the capital of a confederate state with a reputation like Wajo. This place is the boundary of the core area of Wajo to the east, directly adjacent to Wanua Penrang, one of the members of the Wajo confederation closest to the core of Wajo.

After analyzing all the archaeological traces above, the three zones observed have provided an overview of the division and function of space at the time when the Wajo Kingdom grew and developed until the shift of its center to Tosora at the beginning of the 17th century. Archaeological evidence in the three zones confirms that the core of Wajo might be in one of the Zone B area and has experienced several shift of government centers following the succession of the ruling regime in the context of political reformation in the Wajo confederation.

\section{CONCLUSION}

The geographical conditions and the description of the Wajo settlement illustrate the Bugis mentality to adapt and innovate in determining where people live in the lowlands of Walennae and Cenrana. Wet rice agricultural technical expertise enables the creation of an agriculture-based economic space to meet the basic needs of the community (Macknight, 1983, p. 103). Topographically, this place is ideal for living on an agricultural economy basis, apart from providing fertile land, it is also a natural embankment from river overflows during the rainy season.

Referring to the research question, a large number of archaeological traces prove that the Tosora, Cinnotabi and Lamasewanua regions were the zones rich with pre-Islamic religious monuments as well as pottery shards and imported ware from China, Thailand, Vietnam from the periode of Tang to Qing; indicators of population growth for more than two centuries and the opening of the region to cross-island trade at Southeast Asian 
crossovers also called la méditerranée du sud-est asiatique (Lombard, 1970, pp. 841842). The survey of the sites associated with the Wajo-core existence showed differences in occupation space based on a strict timeline. With the exception of Zone A (Tosora) which was clearly the capital of Wajo from the end of the $16^{\text {th }}$ century, surveys in Zones B and $\mathrm{C}$ still require more adequate supporting data to mark specific spatial functions with a clear time sequence. However, before ending this article, it is necessary to give a special note regarding the existence of pre-Islamic sites on the Wajowajoe river which present the old toponyms as described in the LSW manuscript.

The initial phase of Wajo began with the formation of settlements in Penrang by residents who migrated from other places, then assembled under the leadership of spiritual figures who also came from other places. Toponym Penrang is known to be to the east of Zone $\mathrm{C}$; to the north of Lamasewanua, but now the name is used to refer to the name of lake (tapareng) Penrang. Toponym Penrang is also known to be to the east of Zone C; close neighbor of Lamasewanua. Surface data provide information that Penrang and Lamasewanua may refer to the opening of settlements as early as the late $14^{\text {th }}$ century to the early $15^{\text {th }}$ century around Lake Latamperu and Lake Penrang which received water from the Belawae river.

The second phase was marked by the formation of a kind of 'state' as a political unit which was also initiated by one of the old Cina aristocratic descent who brought together the closest settlements (wanuas). LSW states that its center located in Cinnotabi. This regime only lasted for the five periods of Arung which due to circumstances forced the center of the palace to be abandoned. The suspicion that Cinnotabi was founded in the first half of the $15^{\text {th }}$ century has been confirmed by the dating of the oldest ceramic shards from Yue, Qingbai, Lonquan which leads to the early phase of Cinnotabi between the $13^{\text {th }}$ and $14^{\text {th }}$ centuries. There are at least eight sectors that contribute significant archaeological data, in addition to menhirs, pottery and imported ceramics as well as beads, but the exact location of Cinnotabi must be looked for in sectors $\mathrm{C} 7$ and $\mathrm{C} 8$, but more specifically it is recommended to find Cinnotabi's location in sub-sector C7.1 (Sarinyameng), C7.2 (Sekkanasu 1), and C7.3 (Sekkanasu 2).

The third phase is a transitional period with the emergence of the Batara Wajo regime whose center has shifted to a place where Boli tree grew. But toponym Boli is the new name of the current settlement. The survey at this location has not found any traces of artefacts, as is the case in a village called Boli Baru, which is now densely populated. The area closest to the past situation is between Sector C9, particularly in sub-sector C9.1 (Wajo-wajo 1) and C9.2 (Wajo-wajo 2) and C11 (Attunuang), $\quad$ sub-sector $\quad \mathrm{C} 12.1$ (Leppadeppa) and C12.2 (Lamanungke). From the dating of ceramic shards, there is a long period of time between the $14^{\text {th }}$ and $17^{\text {th }}$ centuries with the Lonquan, Qingbai, Zhangzhou shards and also from Thailand and Anam shards. These three potential sectors are located at the triangular-junction of the Wajo-wajoe river. Boli itself according to local tradition is also known as sorengngeng kappala which acts as a port because of its direct access to Salo Cellue.

The fourth phase is the establishment of the new Wajo regime which is marked by the rise of the leadership of Arung Matowa. The LSW text states that the capital remains in Boli, but has since changed to Wajo in order to commemorate the agreement under the shadow of the Bajo or Wajo tree by the expression "ma'bajowajo macekke'mi ri Wajo" means 'we only get shelter under the fresh Wajo' shadow' (Abidin, 1983, p. 478). This information allows speculation that there has been no shift in the center of government even though the regime has changed, so there is no other choice, to find 
the capital of Wajo, as the results of the reforms in Leppadeppa, to be sought at a location between sectors C9 and C12. It is interesting to suggest the capital city of Wajo from the Arung Matowa regime between Wajo-wajo, Boli and Leppadeppa. The three sites are associated with pre-Islamic ritual centers in sectors C12 (Attunuang) and C13 (Tomb complex of Puang ri Magalatung). Meanwhile, sector C15 (Ladua) may play a role as a gateway to the center of government in "Wajo" (new name for Boli) which can be accessed directly from the Pene-pene and Wajo-wajoe rivers.

Taking into account the context of the findings and the relations between spaces, it is necessary to underline as a final note, that the shift of the capital is followed by a relocation of port. In this case, Tosora is a clear example, after the capital was moved to Tosora, the port was also moved to the west side of Tosora, direct access to Salo Cellue, a branch of the Cenrana river. The term 'tosora' itself is taken from the Bugis word, to-sora, which means the place where people are anchored.

\section{ACKNOWLEDGMENT}

My first thanks to The Toyota Foundation for sponsoring this research. I would like to express my gratitude and high appreciation to the Wajo research team for 2001-2002 season: Budianto Hakim, M. Irfan Mahmud, Muhaeminah, Karaeng Demmanari, Manshur, Sumarlin from the Archaeological research office of Makassar; Akin Duli, A.M. Akhmar, Mohammad Nur, Mohammad Tang, Aldi Mulyadi from the Dept. of Archaeology, Hasanuddin University; Agus and Anwar from the Archaeological research office of Bandung, West Java, who participated in the survey and excavation program on the early history of Wajo Kingdom, South Sulawesi.

\section{REFERENCE}

Abidin, A.Z. (1983). "The Emergence of Early Kingdom in South Sulawesi, A Preliminary Remark on Governmental Contracts from the Thirteenth to the Fifteenth Century." Journal of Humanity, Vol 20, No. 4, 21-40.

Bulbeck, D., and Caldwell, I. (2000). Land of Iron: The Historical Archaeology of Luwu and the Cenrana Valley. Results of the Origin of Complex Society in South Sulawesi Project (OXIS). Canberra.

Bulbeck, D. (1992). A Tale of Two Kingdoms, the Historical Archaeology of Gowa and Tallok, South Sulawesi, Indonesia. Australian National University.

Caldwell, I. (1995). Power, State and Society Among the Pre-Islamic Bugis. BKI Deel, 151: 394-431.

Duli, A. (2010). Peranan Tosora Sebagai Pusat Pemerintahan Kerajaan Wajo Abad XVI-XIX. Walennae, 12 (2), 143-158.

Fadillah, M.A., et al. (2002). Laporan Survey Pemukiman Wanua di Kerajaan Wajo, Sulawesi Selatan. Makassar (Unpublished Report).

Fadillah, M.A. (2004). Wanua dalam Konfederasi Wajo: Model Desa Otonom di Tanah Bugis. In, Dias, P \& Muslimin, A.R.E (eds.), Kontinuitas dan Perubahan dalam Sejarah Sulawesi Selatan. Yogyakarta: Penerbit Ombak, 316-355.

Hadimuljono \& Macknight, C. C. (1983). Imported Ceramics in South Sulawesi. Review of 
Indonesian and Malaysian Affaires, 17: 66-80.

Harkantiningsih, N. (2013). Muatan Intan Shipwreck Abad ke-10: Variabilitas dan Kronologi. Amerta, Jurnal Penelitian dan Pengembangan Arkeologi, Vol. 31 No. 2, 81-150.

Hasanuddin. (2017). Situs-Situs Megalitik di Kabupaten Wajo, Sulawesi Selatan. Kapata Arkeologi, Vol. 12 (I), 83-94.

Kalupa, B. 1987. Laporan Ekskavasi Penyelamatan di Desa Tosora Kecamatan Majauleng Kabupaten Wajo, Ujung Pandang (Unpublshed Report).

Lombard, D. (1970). Pour Une Histoire des Villes du Sud-Est Asiatique. Annales Histoire, Sciences Sociales, 25e Année: 842-56.

Macknight, C. C. (1975). The Emergence of Civilization in South Celebes and Elsewhere. In, Pre-colonial State Systems in Southeast Asia, Monographs of The MBRAS, 126-135.

Macknight, C. C. (1983). The Rise of Agriculture in South Sulawesi Before 1600. Review of Indonesian and Malaysian Affairs, 17, 92-116.

Pelras, C. (1996). The Bugis. Oxford: Blackwell Publishers.

Perlras, C. (1971) "Hierarchie et pouvoir tradi- tionnels en pays Wadjo',"Archipel 1 (1971)

Reid, A. (2011). Asia Tenggara dalam Kurun Niaga 1450-1680: Jaringan Perdagangan Global Asia Tenggara. Jakarta: Yayasan Pustaka Obor Indonesia. 
Appnedix 1. Table of Distribution of Imported ceramic shard in Zone C: Lamasewanua

\begin{tabular}{|c|c|c|c|c|c|c|c|c|c|c|c|c|c|}
\hline \multirow{3}{*}{ SECTOR } & \multicolumn{8}{|c|}{ CHINESE } & \multicolumn{2}{|c|}{ THAILAND } & \multirow[t]{3}{*}{ ANAM } & \multirow{3}{*}{ EU } & \multirow{3}{*}{ TOTAL } \\
\hline & \multirow{2}{*}{\begin{tabular}{|c|} 
TANG \\
Yue \\
\end{tabular}} & \multicolumn{2}{|c|}{ SONG } & \multicolumn{3}{|c|}{ MING } & \multicolumn{2}{|c|}{ QING } & \multirow[t]{2}{*}{ SWA } & \multirow[t]{2}{*}{ SUK } & & & \\
\hline & & $Q b$ & Lq & Gu & Cel & $\mathrm{Zh}$ & Jin & $\mathrm{BW}$ & & & & & \\
\hline L1 & 1 & 3 & 9 & 2 & 0 & 3 & 1 & 6 & 24 & 29 & 10 & 0 & 88 \\
\hline L2 & 0 & 0 & 1 & 0 & 0 & 0 & 0 & 0 & 5 & 5 & 6 & 0 & 17 \\
\hline L3 & 0 & 0 & 0 & 1 & 2 & 1 & 1 & 4 & 0 & 1 & 0 & 4 & 14 \\
\hline \multirow[t]{2}{*}{ TOTAL } & 1 & 3 & 10 & 3 & 2 & 4 & 2 & 10 & 29 & 35 & 16 & 4 & 119 \\
\hline & \multicolumn{12}{|c|}{ Note: L1: Lamasewanua-Village 1, S2: Lamasewanua-Cemetery 2, S3: Bulutosompo } & \\
\hline
\end{tabular}

